Симетричність атріовентрикулярного з'єднання у дітей з різними анатомічними варіантами атріовентрикулярної комунікації: ехокардіографічні показники

DOI https://doi.org/10.37336/2707-0700-2019-3-1

\section{Л.А. Шаповал}

ДУ «науково-практичний медичний центр дитячої кардіології та кардіохірургії МОЗ України», м. Київ
Атріовентрикулярна комунікація (АВК) об'єднує групу вроджених вад серця з спільним атріовентрикулярним (АВ) з'єднанням. Дана вада характеризується аномальною будовою АВ перегородки вище і нижче рівня розташування AB клапанів. Наслідком таких анатомічних змін $є$ не тільки порушення цілісності перегородок, а і неправильне формування самих АВ клапанів та геометрії шлуночків [7]. В АВК через отвір спільного АВ клапана з'єднуються обидва передсердя 3 обома шлуночками. Як правило, це з'єднання є симетричним, що зумовлює рівномірний збалансований потік крові до кожного шлуночка. Однак, існує цілий спектр нерівномірного АВ з'єднання, що асоціюється $з$ гіпоплазією лівого або правого шлуночків. В таких випадках АВК визначається як незбалансована та характеризується різним ступенем зміщення АВ з'єднання, гіпоплазі$є ю$ одного 3 шлуночків, а також аномаліями клапанно-хордального апарату спільного АВ клапана [4]. Незбалансована АВК зустрічається в 10-15 \% випадків серед всіх анатомічних варіантів АВК, дві третини 3 них - це праводомінантна форма АВК [7].

Важкі форми незбалансованої АВК передбачають одношлуночкову тактику хірургічного лікування [8]. Визначення можливості проведення двошлуночкової корекції у пацієнтів з помірними формами незбалансованої АВК є складним завданням як для кардіолога, так і для хірурга $[7,8]$. Історично гіпоплазія одного $з$ шлуночків $є$ домінуючим фактором у визначенні незбалансованої АВК. Проте, централізація АВ з'єднання та пов'язані 3 цим порушення анатомії та фізіології АВ при- пливу відіграють головну роль у можливості та доцільності проведення двошлуночкової корекції. Індекс атріовентрикулярних клапанів [1], індекс припливу лівого шлуночка [9] і кут припливу між правим та лівим шлуночками [2] є важливими ехокардіографічними показниками «фізіології припливу». Кожен 3 них $є$ джерелом морфологічної інформації під час проведення ехокардіографічного аналізу цієї складної вади. Проте, взаємозв'язок між цими показниками, а також їх кореляція з розмірами спільного АВ клапана та розмірами шлуночків на сьогоднішній день недостатньо встановлені.

Мета дослідження - проаналізувати ЕхоКГ показники, що визначають дисбаланс у пацієнтів з АВК та провести кореляцію даних показників з розмірами спільного АВ клапана та розмірами шлуночків.

\section{Матеріал \\ та методи дослідження}

3 січня 2014 по грудень 2018 року проведено хірургічне лікування 279 пацієнтам з різними анатомічними варіантами АВК. Середній вік на момент лікування склав $12,7 \pm 3,5$ місяців (діапазон від 27 днів до 8,7 років). Середня вага 7,45 $\pm 2,7$ кг (діапазон від 3,1 кг до 17 кг).

3279 пацієнтів у 245 (87,8 \%) була діагностована збалансована АВК (І група), у решти 34 пацієнтів (12,2 \%) - певний ступінь дисбалансу спільного АВ клапана (II група), 27 (9,8 \%) 3 яких мали незбалансовану праводомінантну АВК, а $7(2,5 \%)$ - незбалансовану ліводомінантну АВК (рис. 1). 


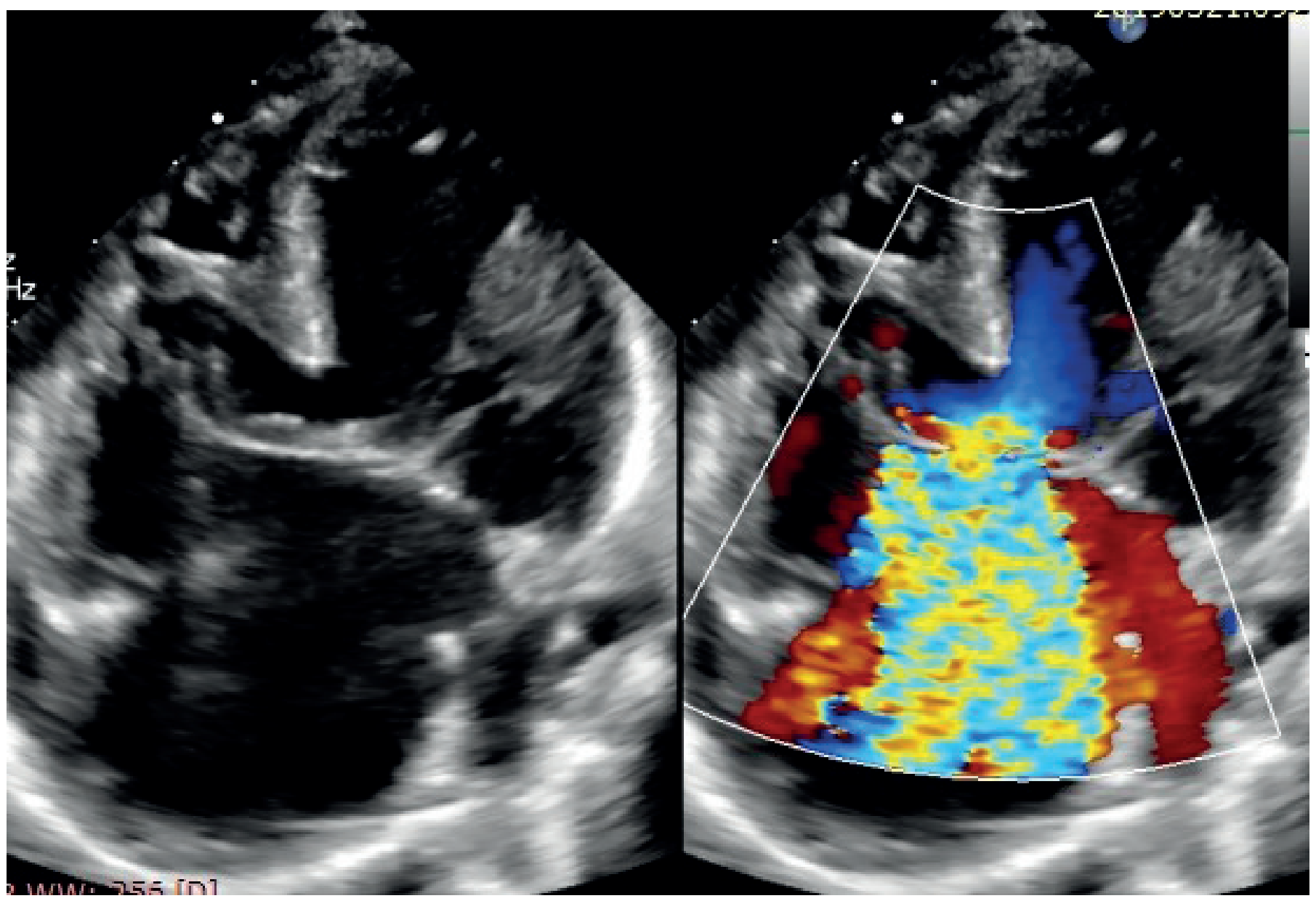

Рис. 1. Пацієнт К. Повна АВК, незбалансована з домінуванням лівого шлуночка форма (тип В за класифікацією Растеллі). Верхня мостовидна стулка кріпиться до аномально розташованого папілярного м'яза в порожнині правого шлуночка. Міжпередсердна перегородка зміщена різко вліво. Праве передсердя з подвійним виходом. Виражена недостатністю спільного АВ клапана. Апікальна 4-х камерна позиція.

Підчас проведення Ехо-КГ обстеження морфометричний аналіз спільного АВ клапана виконувався рутинно і враховувався в діагностичній категоризації обстежених пацієнтів при визначенні відповідної групи та тактики хірургічного лікування. У 165 (59,1%) пацієнтів діагностований синдром Дауна.

Первинна двошлуночкова корекція вади проведена 191 (68,5 \%) пацієнтам. 58 (20,8 \%) пацієнтам початково проведено звужування легеневої артерії. 358 немовлят, яким проведено звужування легеневої артерії, 23 (8,2 \%) в подальшому виконана двошлуночкова корекція вади. Перший етап одношлуночкової корекції виконано $2(0,7$ $\%)$ пацієнтам. Ще $2(0,7$ \%) пацієнтам виконана одношлуночкова корекція після початкового звужування ЛА. В 3 (1,1 \%) випадках проведена півторашлуночкова корекція. Детальна характеристика пацієнтів представлена в таблиці 1.
Характеристику морфологічних особливостей «фізіології припливу» у пацієнтів з АВК проводили з використанням наступних Ехо-КГ показників: модифікований індекс атріовентрикулярного клапана (mAVVI); індекс припливу лівого шлуночка (LVII); кут припливу між правим та лівим шлуночками (RV/LV inflow angle); індекс порожнин шлуночків.

Модифікований індекс атріовентрикулярного клапана (mAVVI) отримували з субкостальної по короткій вісі ЛШ позиції [1]. Обчислювали площу спільного АВ клапана шляхом трасування його по контуру, після чого в передньо-задньому напрямку проводили лінію між гребнем міжшлуночкової перегородки та краєм інфундібулярної перегородки (рис. 2). Дана лінія розділяла спільний АВ клапан на дві частини та розподіляла частину кожного клапана відповідному шлуночку. mAVVI роз- 
Таблиця 1.

Клінічна характеристика пацієнтів (n=279).

\begin{tabular}{|l|c|}
\hline Вік (міс) & $12,7 \pm 3,5$ \\
\hline Вага (кг) & $7,45 \pm 2,7$ \\
\hline Стать (ч/ж) & $136 / 143$ \\
\hline Синдром Дауна & $165(59,1 \%)$ \\
\hline Повна АВК & $192(68,9 \%)$ \\
Неповна АВК & $49(17,6 \%)$ \\
Проміжна АВК & $38(13,6 \%)$ \\
\hline Збалансована АВК & $245(87,8 \%)$ \\
Незбалансована АВК & $34(12,2 \%)$ \\
\hline АВК як ізольована вада серця & $160(57,3 \%)$ \\
\hline АВК +ТФ & $7(2,5 \%)$ \\
\hline АВК+ клапанний стеноз ЛА & $24(8,6 \%)$ \\
\hline АВК +КоАо & $38(13,6 \%)$ \\
\hline АВК + КоАо + обструкція ВТЛШ & $4(1,4 \%)$ \\
\hline Великий ДМШП & $34(12,2 \%)$ \\
\hline Додаткові ДМШП & $12(4,3 \%)$ \\
\hline Первинна двошлуночкова & $191(68,5 \%)$ \\
корекція & \\
Звужування легеневої артерії & $58(20,8 \%)$ \\
Двошлуночкова корекція після & $23(8,2 \%)$ \\
звужування легеневої артерії & \\
Одношлуночкова корекція & $4(1,4 \%)$ \\
Півторашлуночкова корекція & $3(1,1 \%)$ \\
\hline
\end{tabular}

раховували як відношення площі лівої частини спільного АВ клапана до загальної площі спільного AB клапана [8]. Показник mAVVI в межах 0,4-0,6 визначав збалансовану АВК, $\geq$ 0,6 - незбалансовану ліводомінантну АВК $\mathrm{i} \leq$ 0,4 - незбалансовану праводомінантну АВК.

Кут припливу між правим та лівим шлуночками (RV/LV inflow angle) - це кут між латеральними точками кріплення правого та лівого компонентів спільного АВ клапана 3 використанням гребня МШП як вершини кута в апікальній 4-х камерній проекції [2]. Кут формували шляхом проведення ліній від гребня МШП до бокових точок кріплення спільного АВ клапана (рис. 3). У збалансованій АВК кут припливу між правим та лівим шлуночками (RV/LV inflow angle) більш тупий, у незбалансованій - більш гострий. Цей показник потенційно вказує на розмір ДМШП (чим гостріший кут, тим більший розмір ДМШП) та характеризує напрямок трансмітрального кровотоку до ЛШ, що є перпендикулярним у збалансованій АВК, та тангенціальним у незбалансованій ABK [2].

Розрахунок індексу припливу лівого шлуночка (LVII) проводили з використанням режиму кольорового доплера в апікальній 4-х

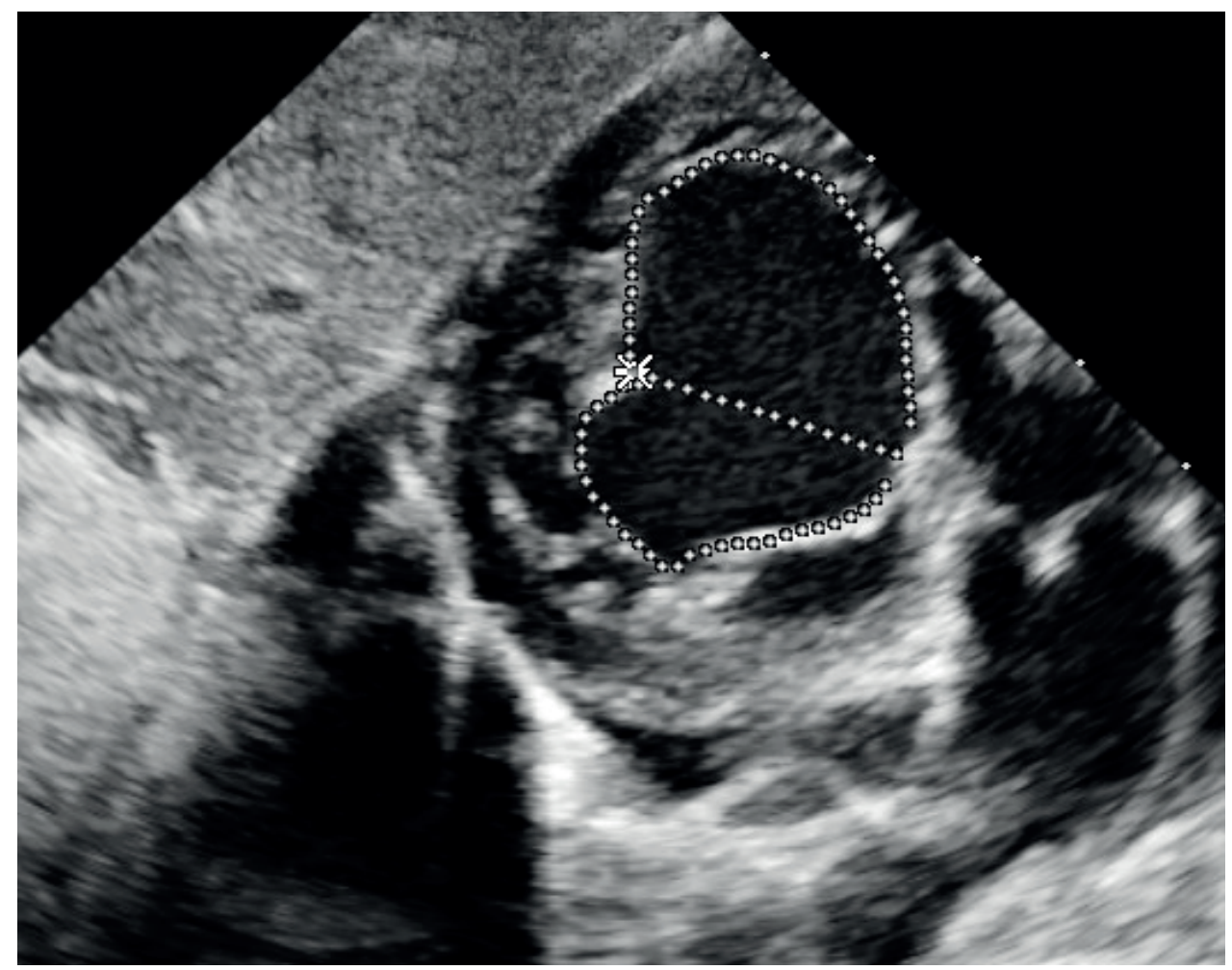

Рис. 2. Пацієнт Б. Повна АВК, незбалансована (праводомінантна) форма. Субкостальна по короткій вісі ЛШ позиція. $m A V V I=0,37$. 


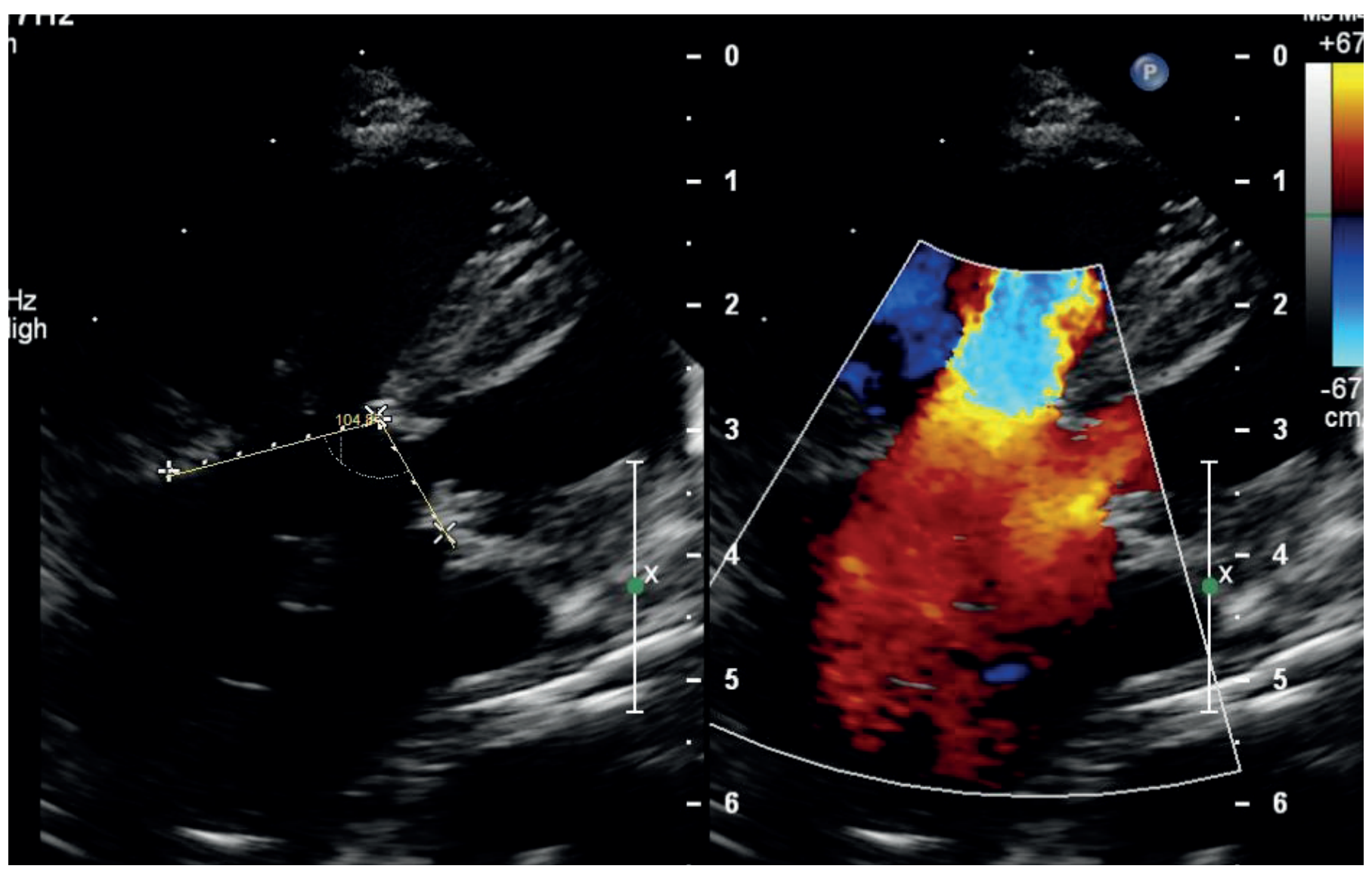

Рис. 3. Пацієнт Б. Повна АВК, незбалансована (праводомінантна) форма. Апікальна 4-х камерна nозииія. RV/LV inflow angle $104^{\circ}$.

камерній проекції [9]. Спочатку у В-режимі двовимірної Ехо-КГ в кінці діастоли вимірювали діаметр анатомічного кільця лівого АВ клапана між медіальною та латеральною точками його кріплення (рис. 4). В кольоровому доплері на рівні папілярних м'язів вимірювали найвужче місце кольорового припливного струменя (вторинний отвір). LVII розраховували як відношення діаметра вторинного отвору припливного кольорового струменя до діаметра анатомічного кільця. Значення LVII 0,50 0,55 характеризує безперешкодний приплив до ЛШ. Значення LVII $<0,50$ асоціюється з підвищеним ризиком смертності у пацієнтів з праводомінантною незбалансованою АВК після двошлуночкової корекції [9].

Індекс порожнин шлуночків розраховували як відношення ширини ЛШ до ширини ПШ, виміряної в кінці діастоли в апікальній 4-х камерній проекції (рис. 5). Вибір даного показника пояснюється технічною неможливістю достовірної оцінки об'ємів шлуночків, особливо правого, методом Ехо-КГ. Лінійні розміри у В-режимі двовимірної Ехо-КГ були доступні в усіх випадках і використовувалися для оцінки відносних розмірів порожнин шлуночків, а не їх об'ємів. Планіметричні виміри більш точно відображають геометричні моделі шлуночків та значно менш залежать від гемодинамічних факторів [6].

Комплексне трансторакальне Ехо-КГ обстеження дітей проводили на УЗ апаратах Philips IE 33 з застосуванням у новонароджених фазованих секторних датчиків S12-10, з частотою 10-12 МГц, у дітей старше місяця - S8-3, 3 частотою 3-8 МГц.

Для статистичного аналізу використовувалась програма SPSS Statistics. Порівняння частот якісних показників у групах проводили шляхом побудови таблиць сполученості $2 \times 2$ із застосуванням критерію хі-квадрат або точного методу Фішера. Рівень достовірності р був двобічний, критерієм статистичної достовірності був $\mathrm{p}<0,05$ та вважався статистично значущим.

Коефіцієнти кореляції Пірсона обчислювали, використовуючи парну делецію між показниками дисбалансу та вимірами порожнин 


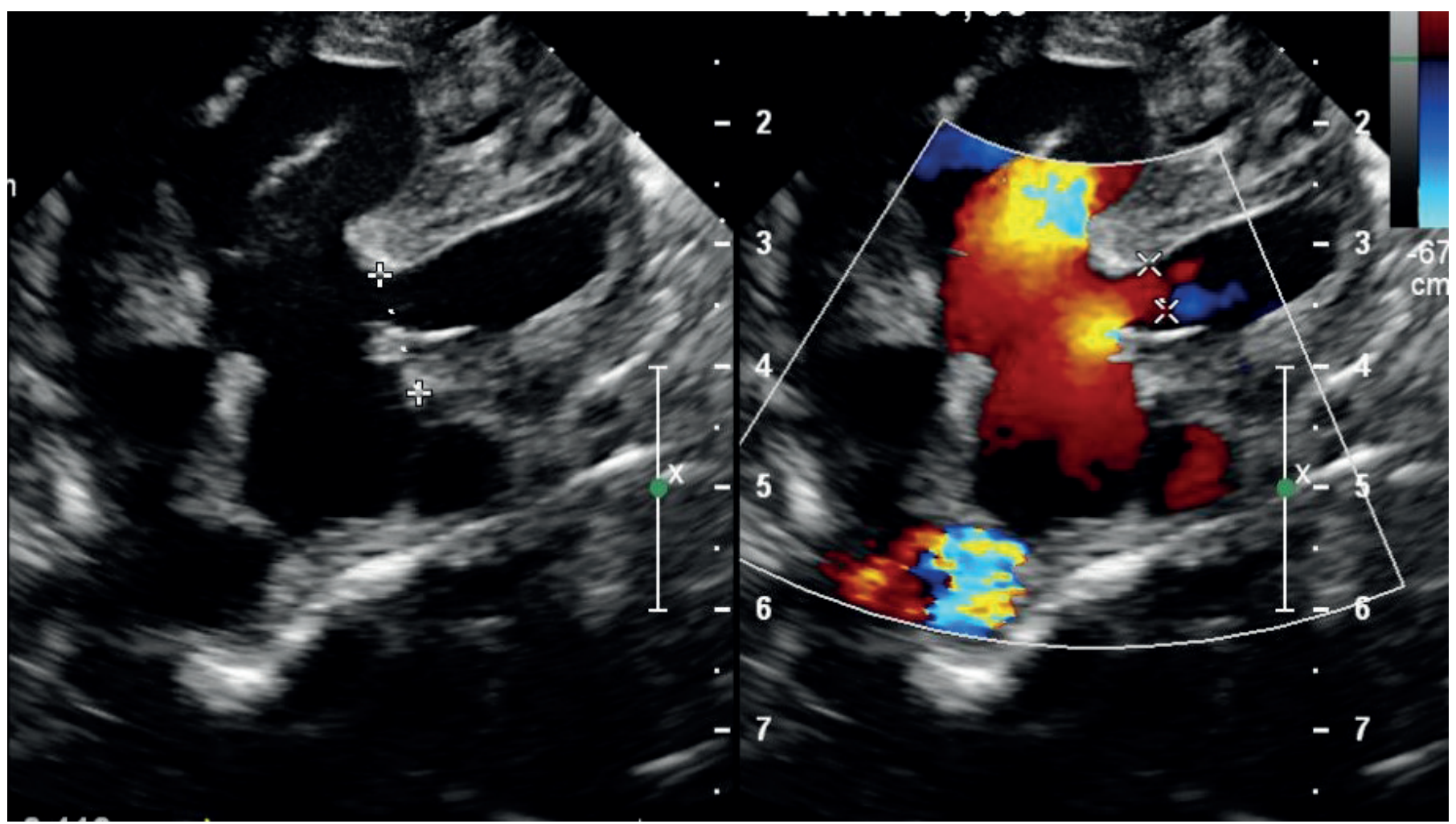

Рис. 4. Пацієнт Б. Повна АВК, незбалансована (праводомінантна) форма. Апікальна 4-х камерна позииія. LVII 0,39.

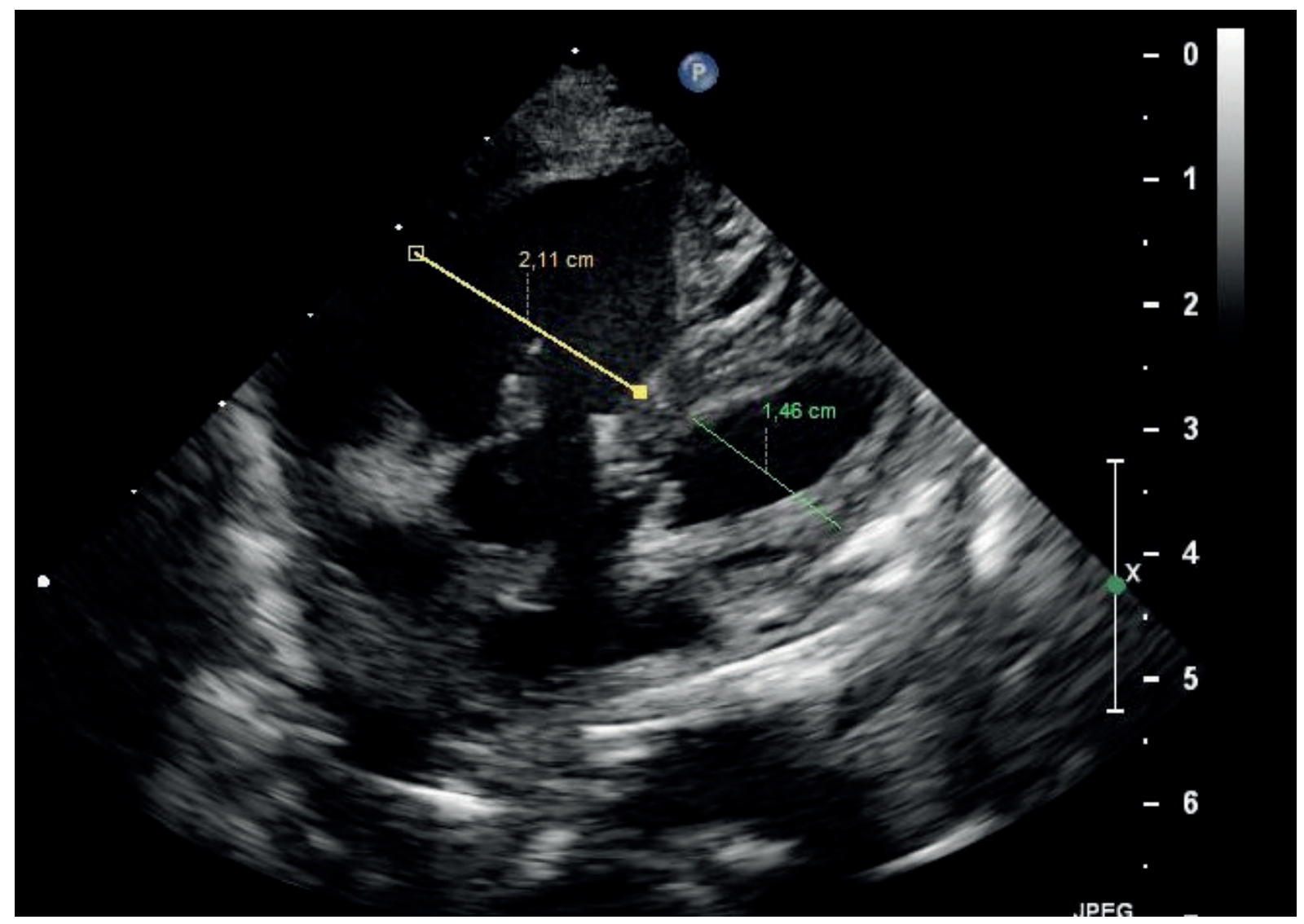

Рис. 5. Пацієнт Б. Повна АВК, незбалансована (праводомінантна) форма. Апікальна 4-х камерна позиція. Індекс порожнин шлуночків 0,69. 
шлуночків для об'єднаної групи пацієнтів. Значення коефіцієнту r від 0,0 до 0,3 визначало слабку кореляцію, від 0,3 до 0,7 вказувало на помірну кореляцію, а > 0,7 - на сильну кореляцію між зазначеними показниками.

\section{Результати та їх обговорення}

В об'єднаній групі, яка складалась з 279 пацієнтів, середнє значення модифікованого індексу АВ клапанів (mAVVI) становило 0,45 \pm 0,09, середнє значення кута припливу між правим та лівим шлуночками (RV/LV inflow angle) склало $125,7^{\circ} \pm 11,2^{\circ}$, середнє значення індексу припливу лівого шлуночка (LVII) було визначено як 0,54 $\pm 0,03$ і середнє значення індексу порожнин шлуночків становило $0,79 \pm 0,38$.

Виявлена помірна кореляціят AVVI з індексом порожнин шлуночків $(\mathrm{r}=0,61, \mathrm{p}<0,0001)$. Не виявлено суттєвої кореляції mAVVI з RV / LV inflow angle $(\mathrm{r}=0,19, \mathrm{p}=0,0078)$. Kрім того, виявлена помірна кореляція між mAVVI 3 LVII $(r=0,34, p<0,0001)$.

Для розуміння отриманих даних проаналізовано середні значення зазначених показників в кожній окремій групі (табл. 2) та визначили фактори, які впливали на остаточний результат.

Як видно з таблиці 2, середні значення $\mathrm{mA-}$ VVI в I та II групі відрізняються між собою.

Передбачалось, що у пацієнтів I групи інші ЕхоКГ показники, що характеризують «фізіологію припливу» та розміри шлуночків також будуть відрізнятися (тобто, будуть значно вищими) в порівнянні з такими ж показниками у пацієнтів II групи.

У більшості пацієнтів I та II групи, mAVVI передбачав відповідний розмір порожнини шлуночків (табл. 2). Проте, середнє значення mAVVI для пацієнтів I групи (збалансована AВК) становило 0,47 $\pm 0,09$ (діапазон 0,42$0,58)$, а середнє значення індексу порожнин шлуночків - 0,74 \pm 0,25 (діапазон 0,66-1,19). Пацієнти II групи, у яких діагностована незбалансована АВК, мали спектр анатомічних особливостей, починаючи від легкого дисбалансу спільного AВ клапана до помірно вираженого дисбалансу спільного АВ клапана з помірно вираженою гіпоплазією одного 3 шлуночків. Середнє значення mAVVI для II групи становило 0,43 $\pm 0,27$ (діапазон 0,32-0,64), середнє значення коефіцієнту порожнин шлуночків $0,74 \pm 0,35$ (діапазон 0,52-1,10). Відсутне співпадіння значень mAVVI між пацієнтами I та II групи. Проте, відзначено співпадіння значень для індексу порожнин шлуночків, причому у пацієнтів I групи на доопераційній Ехо-Кг в 58 випадках визначався помірно гіпоплазований ЛШ з ПШ-сформованою верхівкою серця. Три пацієнти з II групи мали індекс порожнин шлуночків, що перевищував середнє значення даного показника у пацієнтів I групи. Ще один пацієнт мав виражену невідповідність між mAVVI та індексом порожнин шлуночків, що проявилося значним дисбалансом спільного АВ клапана (mAVVI 0,32), але відносно однаковими розмірами порожнини правого та лівого шлуночків (індекс порожнин шлуночків 0,92 ).

Виявлена помірна кореляція між mAVVI та індексом порожнин шлуночків $(\mathrm{r}=0,61, \mathrm{p}<0,0001)$ вказує на те, що як діагностичний інструмент, mAVVI дозволяє ідентифікувати пацієнтів з збалансованою та незбалансованою формами АВК і тільки за оцінкою розміру шлуночка було б невірно визначати ступінь незбалансованості АВК у цих пацієнтів. Диспропорція камер або невідповідність в розмірах порожнин правого та лівого шлуночків у пацієнтів I групи в більшості випадків обумовлена впливом гемодинамічних факторів, а саме переважанням фізіології дефекту міжпередсердної перегородки, а не істинною (морфологічною) гіпоплазією ЛШ [6]. Об'ємне перевантаження правого шлуночка призводить

Таблиця 2.

Характеристика показників «фізіологї̈ припливу» в I та II групах (n=279).

\begin{tabular}{|c|c|c|c|c|}
\hline Показники & І група (n=245) & Діапазон & ІІ група (n=34) & Діапазон \\
\hline mAVVI & $0,47 \pm 0,09$ & $0,42-0,52$ & $0,43 \pm 0,27$ & $0,32-0,64$ \\
\hline $\begin{array}{c}\text { Індекс порожнин } \\
\text { шлуночків }\end{array}$ & $0,74 \pm 0,25$ & $0,66-1,19$ & $0,74 \pm 0,35$ & $0,52-1,1$ \\
\hline RV/LV inflow angle & $125,6^{\circ} \pm 27,4^{\circ}$ & $96^{\circ}-148^{\circ}$ & $123^{\circ} \pm 11,2^{\circ}$ & $92^{\circ}-134^{\circ}$ \\
\hline LVII & $0,55 \pm 0,03$ & $0,5-0,56$ & $0,52 \pm 0,02$ & $0,49-0,53$ \\
\hline
\end{tabular}


до ремоделювання порожнин серця, в наслідок чого відбувається зміна ступеня нахилу міжшлуночкової перегородки в право-лівому напрямку, що сприяє появі «маленького» лівого шлуночка, який фактично може розмістити значно більший об'єм [6]. Гемодинамічні фактори сприяли виникненню невідповідності між розмірами шлуночків та розміром спільного $\mathrm{AB}$ клапана $\mathrm{i}$ для пацієнтів II групи. Виражена недостатність спільного АВ клапана, а також великий розмір ДМШП призводять до об'ємного навантаження на лівий шлуночок. Об'ємне навантаження змінює розміри лівого шлуночка перед операцією i призводить до збільшення морфометричних показників, ніж це було б, якщо б цих факторів не існувало [3]. Така невідповідність спостерігалась у трьох пацієнтів з незбалансованою АВК, які мали виражений дисбаланс спільного АВ клапана і нормальний розмір порожнин ЛШ та ПШ. У всіх трьох були відзначені великі розміри ДМШП, а два $з$ трьох мали виражену недостатність спільного АВ клапана перед операцією.

Середнє значення кута припливу між правим та лівим шлуночками для пацієнтів I групи становило $125,6^{\circ} \pm 27,4^{\circ}$ (діапазон $96^{\circ}-148^{\circ}$ ) і суттєво не відрізнялось від показників отриманих у пацієнтів II групи $123^{\circ} \pm 11,2^{\circ}$ (діапазон $92^{\circ}-134^{\circ}$ ). За даними літератури кут припливу між правим та лівим шлуночками (RV/LV inflow angle) у збалансованих формах є тупим, i більш гострий у незбалансованих формах [2]. 3 зменшенням значення даного показника (RV/LV inflow angle) динаміка припливу до ЛШ поступово погіршується, досягаючи критично скомпрометованого порогу, коли проведення двошлуночкової корекції стає неможливим. Крім того, кут RV/LV inflow angle буде більш гострим за рахунок більш глибокої виїмки міжшлуночкової перегородки. Це спостереження посилається на дослідження Cohen and col. [5], в якому великий розмір ДМШП був фактором ризику незадовільного результату двошлуночкової корекції у пацієнтів з незбалансованою АВК.

У більшості пацієнтів з збалансованою АВК, яким проведена двошлуночкова корекція, середній розмір ДМШП становив $6,7 \pm 2,2$ мм. Але у 32 пацієнтів розмір ДМШП перевищував середнє значення даного показника та знаходився в діапазоні 10-12 мм, ще у 2 пацієнтів розмір ДМШП становив від 14 до 16 мм. Дана морфологічна особливість не перешкоджала проведенню двошлуночкової корекції, але вплинула на зменшення середнього значення $\mathrm{RV} / \mathrm{LV}$ inflow angle в I групі. Не виявлено суттєвої кореляції mAVVI з RV/LV inflow angle ( $\mathrm{r}$ $=0,19, \mathrm{p}=0,0078$ ), що свідчить про те, що RV/ LV inflow angle характеризує динаміку припливу (або напрямок трансмітрального кровотоку) до ЛШ і ніяк не характеризує його розмір.

Індекс припливу лівого шлуночка (LVII) розширює концепцію адекватності припливу до ЛШ шлуночка, включаючи обструкцію для припливу скрізь, де вона може знаходитися (як на рівні спільного АВ клапана, так і на рівні підклапанного простору [9].

LVII характеризує відносний розмір потоку в кольоровому доплері через лівий $\mathrm{AB}$ клапан та забезпечує інформацією про ефективний отвір клапана відносно розміру його анатомічного кільця [9]. Дисплазія лівого АВ клапана, аномалії папілярних м'язів та недостатність спільного АВ клапана спостерігались у пацієнтів обох груп (табл. 3). Однак, значно вищий відсоток пацієнтів II групи мали порушення структурної будови та гемодинамічно значиму недостатність лівого АВ клапана в порівнянні 3 пацієнтами I групи $(\mathrm{p}=0,03)$.

Таблиця 3.

Характеристика анатомічних та гемодинамічних особливостей лівого АВ клапана в I та II гpynax (n=279).

\begin{tabular}{|c|c|c|c|}
\hline $\begin{array}{c}\text { Анатомічні особливості структурної } \\
\text { будови лівого АВ клапана }\end{array}$ & $\begin{array}{c}\mathbf{1} \text { група } \\
\mathbf{n = 2 4 5}\end{array}$ & $\begin{array}{c}\mathbf{2} \text { група } \\
\mathbf{n = 3 4}\end{array}$ & $\mathbf{P}$ \\
\hline $\begin{array}{c}\text { Аномалії папілярних м'язів } \\
\text { (гіпоплазія одного з м'язів) }\end{array}$ & $52(21,2 \%)$ & $26(76,5 \%)$ & $0,01 *$ \\
\hline Парашут деформація лівого АВ клапана & 0 & $3(8,8 \%)$ & $0,03 *$ \\
\hline Подвійний отвір лівого АВ клапана & $5(2,04 \%)$ & $7(20,6 \%)$ & $0,03 *$ \\
\hline Гіпоплазія лівої латеральної стулки & $48(19,6 \%)$ & $27(79,4 \%)$ & $0,01 *$ \\
\hline $\begin{array}{c}\text { Недостатність спільного АВ клапана (помірна до } \\
\text { вираженої) }\end{array}$ & $64(26,1 \%)$ & $31(91,2 \%)$ & $0,03 *$ \\
\hline
\end{tabular}

Примітка: *-різниця статистично значущза. 
Отримана помірна кореляція mAVVI з LVII (r = 0,34, p <0,0001) свідчить про існування відповідності між розміром та функцією клапана, що може бути важливим при розгляді цих ознак разом.

Хірургічний поділ спільного АВ клапана під час виконання двошлуночкової корекції повинен забезпечити формування двох достатньо безперешкодних вхідних отворів $\mathrm{AB}$ клапанів без виникнення в післяопераційному періоді клінічно важливої недостатності або стенозу клапана. При визначенні можливості проведення двошлуночкової корекції повинні враховуватись не тільки розмір спільного АВ клапана, а і його морфологія та функція.

\section{Висновок}

В клінічному використанні Ехо-КГ показники дисбалансу зосереджують увагу на розмірі та функції компонентів спільного АВ клапана, а також розмірі та функції лівого та правого шлуночків. Проведено детальний Ехо-КГ аналіз великої групи пацієнтів з АВК. Виявлена помірна кореляція mAVVI з індексом порожнин шлуночків (r $=0,61, \mathrm{p}<0,0001)$. Не виявлено суттєвої кореляції mAVVI $~$ RV/LV inflow angle ( $r=0,19, p=0,0078$ ). Крім того, виявлена помірна кореляція mAVVI 3 LVII $(r=0,34, p<0,0001)$. Ехо-КГ показники дисбалансу мають слабку або помірну кореляцію один з одним, а також з показниками розміру шлуночків, що свідчить про те, що жоден 3 даних показників не повинен використовуватися ізольовано при визначенні збалансованості та тактики хірургічного лікування у пацієнта з АВК.

Робота $є$ фрагментом НДР «Дослідження морфологічних, патофізіологічних та біохімічних особливостей серця з єдиним шлуночком» (шифр теми ФК 16.00.19, № державної реєстрації 0116U000198).

\section{Література}

1. Echocardiographic definition and surgical decision-making in unbalanced atrioventricular septal defect: a Congenital Heart Surgeons' Society multiinstitutional study. / A. Jegatheeswaran, C. Pizarro, C. Caldarone [et al.] // Circulation. - 2010. - Vol. 122. - P. 209-215. https://doi. org/10.1161/CIRCULATIONAHA.109.925636.

2. Echocardiographic features defining right dominant unbalanced atrioventricular septal defect: a multi-institutional Congenital Heart Surgeons' Society study / M. Cohen, A. Jegatheeswaran, J. Baffa [et al.] // Circ. Cardiovasc. Imaging. - 2013. - Vol. 6. - P. 508-513. https://doi. org/10.1161/CIRCIMAGING.112.000189

3. Feasibility of Biventricular Repair in Right Dominant Unbalanced Atrioventricular Septal Defect: A New Echocardiographic Metric to Refine Surgical Decision-Making / I. Lugones, M. Biancolini, J. Biancolini [et al.] // World J. Pediatr. Congenit. Heart. Surg. - 2017. - Vol. 8. - P. 460-467. https://doi.org/10.1177\%2F2150135117716420

4. Long-term outcomes of single-ventricle palliation for unbalanced atrioventricular septal defects: Fontan survivors do better than previously thought / E. Buratto, X. Ye, G. King [et al.] // J Thorac. Cardiovasc. Surg. - 2017. - Vol. - 153. - P. 430-438. https://doi.org/10.1016/j.jtcvs.2016.09.051.

5. Morphometric analysis of unbalanced common atrioventricular canal using two-dimensional echocardiography / M. Cohen, M. Jacobs, P. Weinberg [et al.] // J Am. Coll. Cardiol. - 1996. - Vol. 28. - P. 1017-1023.

6. Predicting feasibility of biventricular repair of right-dominant unbalanced atrioventricular canal. / J. Van Son, C. Phoon, N. Silverman [et al.] // Ann. Thorac. Surg. - 1997. - Vol. 63. - P.1657-1663.

7. Unbalanced atrioventricular septal defects / D. C. Drinkwater, H. Laks // Thorac. Cardiovasc. Surg. - 1997. - Vol. 9. - P.21-25.

8. Unbalanced atrioventricular septal defect: defining the limits of biventricular repair. / D. Overman, K. Dummer, F. Moga [et al.] // Semin. Thorac. Cardiovasc. Surg. Pediatr. Card. Surg. Annu. - 2013. - Vol. 16. - P. 32-36. https://doi. org/10.1053/j.pcsu.2013.01.009

9. Usefulness of left ventricular inflow index to predict successful biventricular repair in rightdominant unbalanced atrioventricular canal / A. Szwast, B. Marino, J. Rychik [et al.] // Am J Cardiol. - 2011. - Vol. 107. - P. 103-109.

\section{СИМЕТРИЧНІСТЬ АТРІОВЕНТРИКУЛЯР- НОГО З'СДНАННЯ У ДІТЕЙ 3 РІЗНИМИ АНАТОМІЧНИМИ ВАРІАНТАМИ АТРІОВЕНТРИКУЛЯРНОЇ КОМУНІКАЦЇ̈: ЕХОКАРДІОГРАФІЧНІ ПОКАЗНИКИ}

\section{Шаповал Л.А.}

Атріовентрикулярна комунікація (АВК) об'єднує групу вроджених вад серця з спіль- 
ним атріовентрикулярним (АВ) з'єднанням. Симетричність АВ з'єднання та пов'язані 3 цим порушення анатомії та фізіології атріовентрикулярного припливу відіграють головну роль у можливості та доцільності проведення двошлуночкової корекції. Тенденцією сьогоднішнього дня є об'єднання нових концепцій та вже описаних параметрів, що характеризують дисбаланс у пацієнтів з АВК, в єдине ціле, що дозволить відповідним чином обрати оптимальний шлях хірургічного лікування 3 точки зору захворюваності та смертності. В статті проаналізовано взаємозв'язок між основними ехокардіографічними показниками, що характеризують симетричність атріовентрикулярного з'єднання, а саме індекс атріовентрикулярних клапанів, індекс припливу лівого шлуночка та кут припливу між правим та лівим шлуночками та визначена їх кореляція з розмірами спільного АВ клапана та розмірами шлуночків.

Ключові слова: незбалансована атріовентрикулярна комунікація, модифікований індекс атріовентрикулярних клапанів, індекс припливу лівого шлуночка, кут припливу між правим та лівим шлуночками, індекс порожнин шлуночків.

\section{СИММЕТРИЧНОСТЬ АТРИОВЕНТРИКУЛЯРНОГО СОЕДИНЕНИЯ У ДЕТЕЙ \\ С РАЗЛИЧНЫМИ АНАТОМИЧЕСКИМИ ВАРИАНТАМИ \\ АТРИОВЕНТРИКУЛЯРНОЙ КОММУНИКАЦИИ: ЭХОКАРДИОГРАФИЧЕСКИЕ ПОКАЗАТЕЛИ}

\section{Шаповал Л.А.}

Атриовентрикулярная коммуникация (АВК) объединяет группу врожденных пороков сердца с общим атриовентрикулярным (AB) соединением. Симметричность АВ соединения и связанные с этим нарушения анатомии и физиологии атриовентрикулярного притока играют главную роль в возможности и целесообразности проведения двухжелудочковой коррекции. Тенденцией сегодняшнего дня является объединение новых концепций и уже описанных параметров, характеризующих дисбаланс у пациентов с АВК, в единое целое, что позво- лит соответствующим образом выбрать оптимальный путь хирургического лечения с точки зрения заболеваемости и смертности. В статье проанализирована взаимосвязь между основными эхокардиографическими показателями, характеризующими симметричность АВ соединения, а именно модифицированный индекс атриовентрикулярных клапанов, индекс притока левого желудочка, угол притока между правым и левым желудочками и определена их корреляция с размерами общего АВ клапана и размерами желудочков.

Ключевые слова: несбалансированная атриовентрикулярная коммуникация, модифицированный индекс атриовентрикулярных клапанов, индекс притока между правым и левым желудочками, индекс полостей желудочков.

\section{ATRIOVENTRICULAR JUNCTION SYMMETRY IN CHILDREN WITH DIFFERENT ANATOMICAL VARIANTS OF ATRIOVENTRICULAR COMMUNICATION: ECHOCARDIOGRAPHIC PARAMETERS}

\section{L.A. Shapoval}

Atrioventricular (AVC) communication is a group of congenital heart diseases with common atrioventricular connection. The symmetry of the connection and, as a result, anatomy and physiology of atrio-ventricular inflow plays the key role in possibility of double-ventricle correction in this anomaly. Nowadays there is tendency to mix new concepts with described parameters that characterize AVC in one whole guidelines. The ultimate pathway has to be the one that minimizes morbidity and mortality outcomes. In the article author present the correlation between main cardiac echocardiography measurements, that characterize the symmetry of atrio-ventriculat connection (atrio-ventricular valves indexes, left ventricle inflow index, inflow angle between left and right ventricles) and their correlation with size of common atrio-ventricular valve and ventricle's size.

Key words: unbalanced atrioventricular communication, atrioventricular valve index, left ventricular flow index, inflow angle between right and left ventricles, ventricular cavity index. 